\title{
African Approaches to Spatial and Green Planning
}

\author{
Okeke D. C. \\ Research Unit for Environmental Sciences, Department of Urban and Regional Planning, North-West University, Potchefstroom Campus, \\ Potchefstroom, South Africa
}

Email address:

dcokeke2000@yahoo.co.uk, donald.okeke@unn.edu.ng

\section{To cite this article:}

Okeke D. C.. African Approaches to Spatial and Green Planning. Agriculture, Forestry and Fisheries. Special Issue: Planning for Sustainable Communities: Green-Spaces in Rural Areas. Vol. 4, No. 4-1, 2015, pp. 6-13. doi: 10.11648/j.aff.s.2015040401.12

\begin{abstract}
As spatial planning evolved two notions of green planning emerged: traditional and sustainability notions. The former identifies with the practice in African countries when traditional urbanism is the vogue and popular design tradition in planning managed eco-centric settlements. In this context, spatial and green planning fused and drew impetus from the spirituality and traditional institutions of African societies. The sustainability notion of green planning is a recent phenomenon that is common with developed countries although it is assuming global dimension. It came with systemic changes which redefined the instrumentality of spatial planning. In effect, spatial and green planning literarily demerged and the later found expression in green growth otherwise sustainable development. This paper recalls the legacy of green planning in traditional urbanism and the lessons it holds for sustainable urbanism in contemporary societies.
\end{abstract}

Keywords: Spatial Planning, Green Planning, Green Growth, African Cities, Negritude

\section{Introduction}

Before spatial planning was conceptualized as a scientific body of knowledge there were sets of activities which performed the role of planning. These set of activities informed traditional urbanism. They cradled many civilizations in the pre-industrial and pre-capitalist period. Then, Africa made its contribution to spatial planning and this was epitomized in the physical expression of Empires and Kingdoms for the kingdom building societies. The nonkingdom building societies had their peculiar settlement pattern. In both instance, especially in the later, spatial planning was eco-centric and this was driven by the worldview of traditional societies, their survivalist outlook and political structure. Traditional urbanism reflects the spirituality of the people and for the animist societies, like the Ibos in south-east Nigeria, their settlement pattern was directed at transcendental ends. Living with nature was pronounced and this was maintained through code systems of symbols. Minimal interference with nature led development activities.

This outlook changed with the inception of modern town planning following colonization. Since the colonial experience, Africa has leaned on borrowed planning culture, which diffused or, as a matter of fact, was imposed from the global north. The new planning culture was driven by economic rather than cultural and traditionalvaluesystems. The need for change followed imperial interest and consummated with the inception of colonial towns, which are known to serve as trade outlets and conduit for resource marketing. Green planning component of spatial planning lost favor with the ensuing modern urbanism that is built on technological innovations. Over the years, deepening environmental crisis compelled global reaction for remedial measure and this was sought through sustainable development, the application of which is circumstantial in Africa.

The notion of sustainable development inspires green growth. In neo-liberal sense, green growth is not far, in practical terms, from environmental economics built on spatial determinism. However, viewed from environmental perspective, it redefines traditional spatial planning and renews attention on socio-cultural factors and normative value system that affect the use of environment. This revision to traditional standards is being orchestrated as though it is a new concept, safe for its neo-liberal economic agenda, as it relates to Africa. It is argued that the principle of sustainable development is indeed not a new phenomenon [1]. However, in its new shell, given its imperial background, it has problems with recognizing the authority of traditional institutions. Unfortunately, Africa had to contend with this scenario from a dependent status in the world system. 
Otherwise, the neo-liberal notion of green growth prevails.

Africa is subject to the incipient participatory process in planning in a more compelling manner than the originators of the concept in other to contend with sustainable urbanism. The participatory process, which implodes sprawl, defines planning paradigm for project development in Africa. In developed countries the planning paradigm engages urban design to contemplate different models of compact city concept as panacea for sustainability. Incidentally, the attributes of the compact city, which includes workability, high density development, limited size, etc are not too far from the standards of settlement pattern in traditional African societies.

Basically, sustainability is a growth concept notwithstanding its green planning paradigm. As a matter of fact green planning lost its environmental essence in the process of linking green planning with growth in neo-liberal perspective. This paper adopts the annals approach to review the African experience. Hindsight is engaged to track spatial planning of earlier epoch and the evolution of green planning in the context of changing shades of urbanism during the premodern, modern and post-modernist planning periods in Africa. This body of knowledge is linked with modern planning experience to explore the application of urban growth boundaries as instrument for green planning in Africa

\section{Spatial Planning in Africa Under Popular Design Tradition}

The African original contribution to spatial planning was done under the popular design tradition. Then the conception of spatial planning as a body of knowledge is a remote scientific knowledge. The nature of spatial planning in Africa is therefore better understood from the point of appreciating its end product - the African city.

Long before Europeans appeared on the scene, according to [2], Africans 'have created cultures and civilizations, evolved systems of government and systems of thought, and pursued the inner life of the spirit with a passion that has produced some of the finest art known to man'. With the abundance of valuable natural resources in place and their mindset focused, the thrust of their development policy was led by traditions of culture, which were translated into cities in concrete terms through the instrumentality of liberal arts. This rich heritage of African ancestry was rediscovered by intellectual explorers and reserved in a cultural movement called negritude to rescue a main section of humanity from unhappy misunderstanding [2].

Traditional urbanism prevailed in three out of the seven discernable stages in the history of African civilization and state building that nurtured African cities. These stages include; the period prior to $10^{\text {th }}$ century when traditional African Kingdoms flourished; between $10^{\text {th }}$ century and $15^{\text {th }}$ century, the mercantilist period marked by the Trans-Sahara Trade; and between $15^{\text {th }}$ century and mid $19^{\text {th }}$ century, the slave trade period. The other stages are; between mid $19^{\text {th }}$ century and 1960, the colonial period; between1960 and 1970, the independence decade; between 1970 and year 2000, the neo-liberal development concept period; and from 2000 until now the New perspectives on Africa Development (NEPAD) and African Union period.

The planning cultures built on culture and spirituality, which created these towns lost impetus and are unable to revive since colonial experience. According to [3], the development of many African settlements got frozen at a quasi-urban developmental stage. The trend of events witnessed urban planning driven by economic growth imperatives determined with western values. Today, many African cities are considered to be in crisis, as measured by the 'formal' institutional order of late capitalist modernity based on individualism as the basis of social reproduction; on citizenship in a representative democracy administered by a constitutional state as the basis of political relations; and on utilitarian rationality in a system of generational commodity production and market exchange (mediated by state redistribution) as the basis of economic relations [4].

\section{Urbanism in Africa}

Traditional urbanism manifested regional variations in Africa. In Anglophone African countries there were three aspects of interface between town boundaries and community or settlement form: urban pattern, distribution and change. Urban pattern in all aspect of walled cities was characterized with heterogeneous inhabitants arranged in large grains of high density homogeneous quarters segregated along the lines of professional groups, peer groups and kinship ties, etc. Specialist quarters featured prominently especially in Sudanese cities and Kanem Bornu cities in Hausa land. The contrary was the case in the forest area cities of Yoruba land where cities did not feature specialist areas: all craft work was carried on in houses and people practicing the same craft were not grouped together in any way; although each quarter of the town was fairly homogeneous.

Urbanization was generally introverted and urban distribution was concentrated with high dwelling density, mainly for defense reasons and symbiotic living. Nucleated urban form, not extending beyond five kilometers with peripheral greenbelt hemmed in within the town wall, was manifest due to gentrification processes. This caused attention to focus at the center where the hub of political, commercial and religious activities is located or concentrated. Residence at the periphery was uncomfortable due to security reasons. This characterization of the urban form of walled cities in the middle ages was universal irrespective of the nature of city boundaries. The same urban typology can be gleaned in the design of most European cities as well as in central parts of many older cities in North America, Australia and New Zealand [5].

In Francophone African countries the pre-colonial city (imperial city), was socially segregated. This was always the case whenever those in power wanted to plan urban space. According to [6]:...the imperial cities, the capitals of 
theocratic states, the holy cities and the trading posts along the coast were all segregated, but the degree of hierarchisation was dependent on local conditions. The essential elements of the pre-colonial city were the palaces, the mosques and the trading posts.....Urban planning in the imperial city in areas plied by large trucks involved the creation of special spaces, and the use of major highways and elevated sites, all of which addressed the political, military, religious and economic concerns caused by the social conditions.

Writing in Francophone African context, [7] in a review of the literature on the development of the urban phenomenon in the region confirmed that different types of cities have coexisted since the rise of the great empires of the $8^{\text {th }}$ century. These are imperial cities, trading posts, and colonial cities. This collaborates the various account by Arab merchants and Portuguese explorers concerning tales of flourishing African cities some of them founded on the successive sessions of Ghana $\left(8^{\text {th }}\right.$ century $-11^{\text {th }}$ century $)$ Mali $\left(12^{\text {th }}\right.$ century$14^{\text {th }}$ century) and Songhai $\left(15^{\text {th }}\right.$ century- $16^{\text {th }}$ century) empires [8]. There were tales of desert area Sudanese towns of Tekrur, Audoghast, Oulata (Walata), Timbuktu, Gao and Agadez; the southern belt of towns which included Segou, Djenne, Ouagadougou, Oyo, Katsina and Kano; the east Africa citystates of Mogadishu, Mombasa, Zanziba, Kilwa; and the 'Kraals' of Zulu Kingdoms in southern Africa. These imperial cities grew up when international trade between the Mediterranean, Europe and the Far East was expanding rapidly [9].

With the inception of modern urbanism in mid- $19^{\text {th }}$ century African city heritage paled into insignificance. African cities remained organic as Africa served within the period (perhaps until now) as source region for global economy and ostensibly for the growth of western civilization. This was, and is still, being achieved through unfavorable trade relations - the type that led to colonization. The unfortunate situation truncated city development in divergent ways in sub-Saharan Africa. Strategically, the integrated cosmology of traditional Africa was replaced with single-minded utilitarian objectives which produced utilitarian designs for cities in Africa. The design options bulldozed away cultural symbols, behavior, and beliefs that determined the system of base of traditional African cities. Cities in Africa became hybrids, an inevitable product of intervening culture and policy formulation hegemony spurn abroad.

Overall, from the mid 19th century, cities in Africa were no longer 'African cities' both in character and in function, because the institutional framework on which they existed altered significantly. 'African cities' became cities in the Diaspora in their homeland as the world system bear on contemporary African development. As a matter of fact, it seems, since the attempt in the colonial period to import liberal capitalism and make it blend with the social nature of African society, cities in Africa tend to drift awkwardly along unfamiliar courses charted by globalization or more precisely, neo-liberalism as global economic orthodoxy.

In mid-1990s sustainable urbanism gained attention as an advocacy of the UN-Habitat. Sustainability, which is the theoretical base of sustainable urbanism, has been severally explained. The principles of sustainability concept is not as confusing as its practice and more so in the African context. There are wide ranging definitions of sustainability. They all talk about development that does not jeopardize the ability of future generations to meet their own needs. Urban productivity and regional integration as well as concerns for unsustainable level of resource consumption in cities, especially those characterized by urban sprawl, led sustainability to appear in urban planning theory. Urban sustainability therefore emerged as a planning concept. The objectives of urban sustainability as suggested by both UN's Agenda 21 and Habitat Agenda [10] include: 'a compact urban form; the preservation of open space and sensitive ecosystems; reduced automobile use; reduced waste and pollution; the creation of liveable and community-oriented human environments; decent, affordable, and appropriately located housing; improved social equity and opportunities for the least advantaged; and the development of a restorative local economy'.

With this background [11] identified six operational principles of sustainable development thus: harmony with nature, livable built environment, place-based economy, that is, a local economy should strive to operate within natural system limits, equity, polluters pay, and responsible regionalism. With these provisions it is fairly clear what sustainability is out to achieve, but reactions to these principles is where the problem lies. This reflects in the instruments and strategies applied in the administration of sustainable development. Reactions in developed countries indicate recourse to spatial models of urban sustainability. Some notable examples include the urban compaction model in Britain and New Zealand, urban consolidation or urban intensification model in Australia, growth limit and the rise of new urbanism in USA, regional urban containment model in Britain, amongst others. In essence renewed focus on quality urban design proclaimed sustainable urbanism.

The situation in Africa did not reflect the same focus on quality urban design. Rather, there is an increasing tendency of addressing cross-cutting issues and not core issues in planning. Environmental management and decentralization policies now effectively usurp urban policies. Hence, attention drifts from spatio-physical aspects of urban form, expressed in the urbanity of cities, to urban quality issues that dwell on degradation in socio-economic and environmental terms. This explains in part the frail relation between modernist and post-modernist planning. More significantly, it explains to a great extent the paradigm shift in planning, which has had a chequered history epitomized in the 1980s.

The trend of a paradigm shift in planning has regional peculiarities in Africa. For Francophone Africa it moved from physical planning to action planning leading to planning tools such as urban reference plans, urban audit plans, urban contract plans and urban grid plans, all for purposes of implementing urban projects. Next to action planning is strategic development planning, with its strengths and 
weaknesses, and finally there is a move to localizing the Millennium Development Goals (MDGs). For Anglophone Africa the successive approaches are comprehensive master planning, action planning, structure planning, strategic planning, community planning, sustainable cities programme (SCP), city development strategies (CDS), and an infrastructure-led development approach. Reference [12] claimed that a more comprehensive urban-rural inter-linkages perspective or regional planning approach to planning is being advanced and promoted courtesy of UN-Habitat contributions. He further claimed that many countries have imbibed the new perspective, although this is not very visible in literature. Moreover, a lot depend on the nature of linkage in anticipation because linkages could be backward and unproductive. Such linkages are based on survivalist objectives which UN tend to advocate for the so-called 'poor environments' found in Africa.

As a result of these trends, thematic treatment of planning is the vogue, hence the emergence of sectoral planning. The subject matter of planning transits to poverty issues, thus propoor planning coupled with the consideration of informality serve as core characteristic features of planning initiatives. In the circumstances, independent nations tend to find their own synthesis depending on their local conditions, however, seldom with regard to regional (territorial) integration. Most of the planning initiatives are driven by the prevailing neoliberal planning theory although the resilience of formal planning theory is noticed and it is remarkably acknowledged by UN-Habitat. The economic basis of growth which neoliberal planning theory seeks further redefines the sustainability notion of green planning. In the circumstance, green planning gradually assumes the status of an economic concept,subject to the economic goal of sustainability.

\section{Spatial Planning in AfricaUnder Professional Design Tradition}

There are basically two dimensions of spatial planning in Africa and they are; urban design which defines the urbanity of cities and regional integration otherwise spatial distribution of development projects which defines the space economy. Both dimensions work complimentarily in premodern planning as a unified activity under local authority. In modern planning their determinant factors tended to polarize under globalization. The former is guided by planning rationality while the later is guided by market force. Planning rationality aligns with urban planning and design which deals with land use management and identifies with the traditional notion of green planning. In this case spatial equilibrium is the focal point therefore spatial planning is synonymous with urban planning. On the other hand, spatial planning which defines the space economy theoretically addresses the economic and spatio-physical bases of development. In practical terms, since the modernist planning period, spatial planning seems not to address spatio-physical bases of development. Its attention increasingly focus on the economic basis of development, hence it is concerned more with spatial determinism in economics otherwise environmental economics. It therefore connects with the sustainability notion of green planning. These seemingly divergent tendencies influence current thoughts about spatial planning in Africa.

In a general reassessment of urban planning in African cities [12] master planning prevailed in the 1930's-1960's, followed by disjointed incrementalism in 1970's, structural planning in 1980's and lastly action planning since 1990's. With the inception of colonial urbanization in mid $19^{\text {th }}$ century until the independence decade in the 1960s the instruments for urban design in Africa, precisely Anglophone Africa, were imported as direct product of professional design tradition in urban planning in Europe; especially British town planning laws, the Town and Country Planning Act of 1947. A different approach somehow applied in Francophone Africa where colonial authorities fabricated planning instruments insitu given circumstantial conditions. According to [13] both approaches focused on legislative provisions: ...for the planning of regions, district and local areas, development control, subdivisions and consolidations, acquisition and disposal of land with the objective of conserving and improving the physical environment and in particular promoting health, safety, order, amenity, convenience and general welfare, as well as efficiency and economy in the process of development and improvement of communications; authorization of the making of regional plans, master plans and local plans, whether urban or rural; the protection of urban and rural amenities and the preservation of buildings and trees and generally to regulate the appearance of the townscape and landscape; the acquisition of land; the control over development including use, of land and buildings; regulation of subdivision and the consolidation of pieces of land; and matters incidental to or connected with the foregoing.

Planning legislation was backed-up with planning standards, housing standards, building codes, land acquisition acts, and scores of by-laws relating to model building, health, hawkers/vendors, shop licensing, liquor, and premise. Other back-up provisions include General Development Order/Interim Development Order, labor relations, public health act, local government act, urban council, district council, and rural councils act, local government finances act, local government service act, mines and mineral act, etc. [13].Admittedly this represents a fairly comprehensive list of legal provisions but remarkably it de-emphasized provisions for green conservation and culture. The focus was on developing the city as engines of growth and not as crucibles of development which is culture specific.

Master plans prepared within the first half of $20^{\text {th }}$ century especially by French architects under the influence of Le Corbusier are ubiquitous. Within the same period Japan experimented directly with imposed master planning and Western urban forms in what were then its own colonies of Taiwan, Korea, China and Manchuria [14].India and Latin American cities involvement is outstanding. 
The national governments inherited the colonial planning instruments. By 1970s the master planning instrument had undergone severe criticisms. There are two shades of criticism; those against master planning instrument and those against modernist planning which engage master planning instrument. The criticism against master planning dates back to the mid- $20^{\text {th }}$ century in Europe and in mid-1960s and early 1970s it filtered to Africa. In Europe critics questioned the validity of MPA in a pluralistic society. In Africa critics claim that it is not indigenous hence non-compliant with local institutions and that it is restrictive and exclusionary. The planning standards are also held to be restrictive, imperial, inflexible, non-standardized, and unrealistic. Similar criticism applies to development control, which in addition to the already mentioned shortcomings is regarded as negative and reactive. In some instances there are reservations about the adequacy of the statutory provisions. For example land use acts tend to create land administration problems; mines and minerals act usurps development control; General Development Order conflicts with by-laws; and there is high ignorance and corrupt practices in the application of by-laws.

The nationalist governments applied national development plans which adopted the notion of spatial planning based on the spatial distribution of development projects. A variety of these national development plans focused mainly on regional economic development. These development plans have spatial content such as those of Nigeria in the 1970's to 1990's before the rolling plan periods. They contest for position with predating UN-Habitat alternatives. Most of the UN-Habitat models (IUDIP, PEDP, etc) were introduced as follow-up to the launch of neo-liberal theories of development in Africa in the 1980's. Meanwhile traditional master planning continues in several contexts [17].

In early 1980 s democratization of the planning machinery ensued and attention focused on community participation. In Francophone Africa the period 1960-1990 marked the municipal administration phase when decentralization slowed down after an initial fast take off at the end of Second World War. Decentralization process revived in 1990-2000 period, which marked the urban management phase when planning consultancy peaked off, and 2000 until now, seen as local development phase, marked the passage of rhetoric on decentralization to actually putting in place local development mechanisms involving various categories of stakeholders.

It is therefore not uncommon that urban institutional and regulatory frameworks that are used in several Anglophone African countries and indeed preferred by central or state level governments are multi-purpose bodies or organs, variously called "Urban Development Corporations", "Urban Development Boards", "Urban Development Authorities", "Planning Authorities", etc. - which had since national political independence been used with significant positive effects and outcomes [12].These organizations are held to effect the envisaged integrated city development, ensuring that planning and development decisions are made in the overall public interest. It is however recognized that public interest may not necessarily always be the same as the interest of all.

Indeed, the urban planning process began to involve, admit of and be affected by a wider variety of participant actors including from the government (central, state/regional and local levels), community and neighborhood associations as well as other civil society stakeholders and interest groups. Considering the weak status of civil society in Africa inclusive participatory planning is more or less induced as a fall out of international development discourse. The discourse built support for the new planning methodology with "subsidiarity principle" a concept which advocates that "decisions should be made and services provided at the lowest level that is cost-effective without creating too many over-spill effects" [12].

In Anglophone Africa the new process, which is experiencing difficult to pick up, tends to significantly slow down planning decisions, administrative and delivery processes and participation is compelled by lack of political will and logistics to be limited to consultation. In Francophone Africa collaborative planning approaches actually started to evolve in the 1960s. The new approaches are technocratic and normative, consulting the beneficiaries is nonetheless mandatory [15].However, the welfare state took responsibility for planning and relegated people's participation to the background.

Current trend indicate the review and revision of most regulations with the aim of creating enabling rather than restrictive environment. A lot of reviews have already taken place especially with planning laws but pragmatic application is still lacking as in Nigeria with the new Urban and Regional Planning Decree 88 of 1992.Most reviews take the form of capacity building and reorientation that build on existing theoretical foundations, however they seek decentralization and democratization of planning decisions. The prime motive is to accommodate the informal sector in urban planning and to make planning instruments implementation-oriented. This is considered an imperial agenda, considering the remote causal factors of the informal sector which are connected with the installation and sustenance of extroverted space economy in Africa.

Urban planning practice in Africa is yet to step into the arena of urban sustainability that is built on design-oriented approach to urban resource management. This feat is not being addressed with the incidence of ${ }^{\prime}$ architectural approach to planning' which provides contemporary critics ([16], [17], [18]) foundation for their continual criticism against master planning instrument. Rather than urban sustainability attention is focused on environmental sustainability which indicates preference for environmental action plan. Therefore plans are encouraged to be either sector specific or project specific or specific to levels of intervention that is national, regional or urban level. These approaches are given multiple variants of adjectival qualifications that are sometimes confusing. In fact some of the new ideas via-off the professional mandate of spatial planning practice. A typical example is the Environmental Planning and Management 
(EPM) approach of UN-Habitat sustainable cities program. What transpired in reality in EPM is nowhere near the green planning that is associated with sustainable development. It was more or less pro-poor planning efforts, which were appraised by the UN to be unsuccessful because it did not resonate with local institutions [13]. .

At least in theory, international criticism of master planning generated some dynamics in the planning system of some African countries. In South Africa, with a relatively developed planning system in the region, fortified with scores of policies, guidelines and legislation aptly summarized by [19], measures consistent with current planning thoughts were adopted. The overall objective was to alienate master planning. Master plans which prevailed in pre-independence period [20] transited to strategic plans in the form of 'guide plans' and later 'structure plans' to manage the overall growth of areas [21].After 1994 it got to strategic spatial planning. Eventually from 2000, spatial frameworks were required as an element of statutory integrated development plans (IDPs): strategic plans intended to guide the work of municipalities [22]. What transpired in practice in early 2000 and apparently until now was heavily criticized to be below expectation ([23], [24], [25], [18], [19].

As it is consistently the case, detailed end-state planning continued to direct land use change in spite of spatial development planning that was theoretically in vogue. Reference [22] reaffirmed this position in the analysis they provided for Ekurhuleni metropolitan municipality, South Africa. Internationally, in the 1980s, cities in China and East and South-east Asia hitherto without institutionalized planning system adopted master planning amidst the contemplative scenario for new innovations in urban planning. Remarkably Singapore and Hongkong within the Asian bloc have long standing and successful experience with master planning. The new entrant China was formally rehabilitated with the City Planning Act of 1989, which set up a comprehensive urban planning system based on the production of master plans to guide the growth of China's burgeoning new cities [26][27].Naturally they adopted the new master planning approach which emphasized concern for implementation.

Summarily there are about five discernable features that mark urban planning in Africa. They are, the resilience of informality in the transition from traditional (pre-colonial) to modern (colonial) urban planning, the evolution of legislation in urban planning, poor relationship between rhetorical and practical meaning of urban planning concept, the controversy of master planning, and the commitment of external assistance agencies to sponsor new approaches to urban planning or what could be termed 'neo-liberal urban planning' approach in Africa. The ambivalence of the African society towards these new approaches to spatial planning cannot be ignored. However, the new approaches bear overlapping influence that makes it difficult to discern the direction of urban planning in Africa. The tendency is for individual nations to find their own synthesis for urban planning depending on their local conditions but with little regard for regional integration. Except perhaps for South Africa, common impression indicate the incidence of declining performance of urban planning and the erosion of its relevance in the scheme of national development. In the whole scenario it seems a fundamental misconception of urban planning exists where urban planning and project planning tend to be perceived interchangeably and used synonymously. This reflects in the mixed-bag of development of contemporary African cities, a phenomenon that is responsible for the inherent process of sprawling urban growth, urban crime, poor environmental quality, declining productivity, and dysfunctional infrastructural and activity systems, etc.

\section{Contribution: Urban Growth Boundary Instrument for Green Planning in Africa}

The sustainability notion of green planning is a redundant concept in Africa given the poor performance of the SCP/EPM initiative and several other neo-liberal planning initiatives directed at sustainable development. It is not clear how this notion performs in developed countries where quality urban design holds sway for urban sustainability. Most of the principles of urban design concerning green planning draw from the traditional notion. This is why green planning still relates to forest reserves, recreation areas, greenbelts, national parks, zoological gardens, etc. The phenomenon of smart growth, Greenfield and Brownfield development comes into play as spatial planning serves as conservation instrument.

Growth boundaries play a determinant role in traditional urbanism, both for developed and developing countries. In Africa, growth boundaries were conceptualized as town walls. The town wall took many forms and it is used for many purposes especially delimiting Brownfield development. This instrument in urban design played a formidable role in the traditional notion of green planning. Today, the same town wall concept is re-invented as Urban Growth Boundaries (UGBs) and applied as best practice mechanism for urban growth management. Reminiscences of this ancient practice hold lessons for green growth in contemporary planning.

The traditional form of UGB was 'Green Belt'. In developed countries, Britain pioneered this practice in mid$20^{\text {th }}$ century as a reaction to finding planning solution to spatial distortions in economic land use responsible for urban productivity decline. Simply the rationale for 'Green Belt' in developed countries is spatial growth-related. Britain adopted the 'Green Belt' and UGB concepts that provide limits for urban expansion. As a matter of fact England is regarded as home of 'Green Belts' and UGB. London is surrounded by a boundary and a 900 square mile Green Belt. Copenhagen is also surrounded by a boundary and 'green wedges' of open space.

Majority of traditional African cities, ranging from the city-states of the southern Sudan empires to the cities of 
forest area empires of West Africa, adopted town walls. Town walls of great length (Kano, $22 \mathrm{~km}$; Ibadan, 16km; Old Oyo, $25 \mathrm{~km}$ ) identified these city states around $15^{\text {th }}$ century to $18^{\text {th }}$ century.

The boundary wall for towns was mud structures and for villages boundary wall was matting or corn stalks. Until the $18^{\text {th }}$ century the boundaries of cities of the coast of East Africa were poorly constructed because the inhabitants relied on cooperation with the hinterland, defense was not a critical issue. For inland East Africa the towns of traditional Chwezi kingdom were surrounded by defensive ditches sometimes cut right into the bedrock, and within the towns the chief's house and cattle Kraal were also surrounded by ditches [2].In Central Africa as in Ibo-land of West Africa the subconscious formality of invisible boundaries recognized by the inhabitants was a common feature in the axial plan of cities. Some cities of the Sudanese empire such as Kumbi were surrounded with the moat and some others especially in Zululand under Shaka in southern Africa was surrounded with barren 'buffer zone' deliberately created to work against penetration by migrants.

Town boundaries commonly defined with town wall should not be mistaken for internal walls referred to as urban boundaries that are manifest in contemporary cities. Both features are conceptually and mutually different, although a relationship is being observed between the two concepts. While internal walls or urban boundaries explain divisions or boundaries within the urban fabric, town walls or town boundaries define the limits within which urban activities are confined. In other words boundary walls circumscribe the perimeter boundary or limits of traditional settlements. This limit was not provided entirely then by constructed mud walls. In most cases the mud walls were used to provide protection for the exposed flanks of the settlement which was not covered by natural barriers.

However, irrespective of the features that make up these boundaries the town boundaries were intended to provide defense against threats of predating animals and human enemies. Also it gave identity to its inhabitants and protects the authority of sovereign city states. Beyond physical protection provided by the sense of enclosure, the walls provide psychological reassurance. Hence town walls were more than bricks and mortar; they were in effect boundaries between two worlds responsible for 'them and us' syndrome associated with social relations in traditional cities. This is responsible for the cause-effect relationship that tend to exist between town walls (external boundaries) and urban boundaries (internal boundaries) in which case the presence of town walls cause the disintegration of internal boundaries.

The rationale for town walls in Africa relates to territorial definition, defense mechanism and limits of urban activities. Transition from walled cities occurred with the inception of modern urbanism when automobile development assumed prominence as dominant morphological factor that influence urban form. Cities could now spread up to twenty or thirty kilometers outwards depending on available technology. The growth factor which informs the sustainability notion of green planning lacks the spatial dimension which the rationale for UGB instrument shares with town walls. Sustainability and UGB are rarely related in literature but their relationship could be conveniently implied.

Irrespective of sustainability, the UGB concept is currently being applied in America, Europe, Middle East, North and South Africa. ASEAN countries are favorably disposed to borderless cities. East and West African countries seem to be non-aligned. The UGB concept was introduced in South Africa in the 1970's by the Natal Town and Regional Planning Commission of the Province of Natal (now known as KwaZulu-Natal) in the regional guide plans for Durban and Pietermaritzburg. The concept was at that stage termed an Urban Fence. The urban fence strategy was incorporated in the Integrated Development Plan that is required for all local authorities in South Africa. This plan would as one of its components include a Spatial Development Framework plan which would normally, certainly for the larger metropolitan areas, indicate an Urban Edge beyond which urban type development would be severely limited or restricted (Metropolitan Durban - Draft Guide Plan, Natal Town and Regional Planning Reports Volume 28, 1974.).However,[28] in his study on why South Africa continues to build unsustainable cities indicated that UGB concept cannot be applied in South Africa. The North African experience is barely recorded.

\section{Conclusion}

The primary challenge facing Africa is to stabilize its urban system and in the process introvert the space economy to localize productivity. Therefore spatial planning needs to be guided by spatial integration targeted at redressing distortions in the urban region, which are responsible for urban productivity decline. Paradigm shift is inevitable to mobilize operations in this direction, but not in the sense of neo-liberal planning. Neo-liberalism itself will be subject to change to an alternative development ideology that is compliant with the objectives of African renaissance. Neomercantilism contends for this position, considering the epistemology of African civilization. It will serve as thinking instrument for paradigm shift in planning, which will favor territorial planning. This is top in the agenda for further research. The current drift towards neo-liberal participatory planning which is project oriented is antithetical to green planning in Africa. It seldom supports green growth and cannot be used to establish green infrastructure network - an activity that exists at the realm of (re)modeling the urban form. According to Amundsen, [29] green infrastructure is both a process and product, presumably in the same manner with formal spatial planning for Africa.

Africa cannot afford to alienate spatial planning in favor of increased emphasis on public participation and consensus in planning whereby the wishes of individual, small groups and the popularity of politicians shape urban destiny. So far there has been an over-reaction on the part of urban planners leading to excessive participation and the neglect of physical 
planning. Africa must learn from quality urban design practiced by developed countries. The basic requirement now is the revision of current trend towards framework planning. This contribution postulates the use of urban growth boundaries (UGBs) to capacitate master planning as a strategic move towards managing Greenfield and Brownfield development in Africa. The overall effect of reworking the space economy is the ultimate goal. Policy reforms are therefore imperative to re-instate inter alia the traditional notion of green planning in the global concept of sustainable urbanism. There is no gainsaying that the sustainability notion of green planning is arguably an illusion in neo-liberal urbanism in Africa.

\section{References}

[1] C. B. Schoeman,Urban planning and the interface with environmental management and transportation planning.Series H: Inaugural Address: NR. 2010, pp. 1-40.

[2] B. Davison, and The Editors of Time-Life BooksAfrica KingdomsTime-Life Books, New York. 1966, p.37

[3] C. Rakodi, 2 Global forces, urban change, and urban management in Africa. (In Carole, R. ed The urban challenge in Africa: Growth and management of its large cities. United Nations University Press. TokyoNew YorkParis. 1997

[4] P. Jenkins, African cities: competing claims on urban land.(In Locatelli, F. \& Nugent, P.edsAfrican cities; competing claims and urban spaces.Brill. Leiden.: 2009, pp81-107.

[5] J. Arbury,From urban sprawl to compact city - an analysis of urban growth management in Auckland.(Unpublished Thesis Auckland University, Auckland) (http://portal.jarbury.net/thesis.pdf)2005Date of access: $14^{\text {th }}$ May 2011.

[6] K. Attahi; D. Hinin-Moustapha, \&K. Appessikaa,Revisiting urban planning in the Sub-Saharan francophone Africa. (Being a regional study prepared for revisiting urban planning: global report on human settlements). 2009 Available from http://www.unhabitat.org/grhs/2009.

[7] C. Coquery-Vidrovitch,Processus d'urbanization en Afrique.Tome I \&II Harmattan. Paris. 1988

[8] C. Coquery-Vidrovitch,The Process of Urbanization in Africa (From theorigins to the beginning of independence)African Studies Review 34,1991,pp.73.

[9] S. Denyer,African traditional architecture: an historical and geographical perspective.Africana Publishing Company. New York. 1978, pp. 31.

[10] S. Wheeler,Planning for metropolitan sustainability.Journal of Planning Education and Research. 20.2000, pp. 134.

[11] P. Berke, \&M. Manta-Conroy,Are we planning for sustainable development? An evaluation of 30 comprehensive plans.Journal of the American Planning Association. 66(1): pp. 21-33. 2000.

[12] D. Okpala, Regional overview of the status of urban planning and planning practice in Anglophone (Sub-Saharan) Africa.(Being a regional study prepared for revisiting urban planning: global report on human settlements.) 2009 Available from http://www.unhabitat.org/grhs/2009.

[13] United Nations Centerfor Human Settlement (UNCHS)Reassessment of urban planning and development regulations in African cities.Nairobi, Kenya: UNCHS.1999.

[14] V. Watson, The planned city sweeps the poor away...:urban planning and $21^{\text {st }}$ century urbanization.Progress in planning. 72:153-193. 2009.

[15] UN-Habitat. Sustainable urbanization: revisiting the role of urban planning, global report on human settlement. Nairobi: UN-Habitat. 2009.

[16] A. Mabin, \&D. Smit,Reconstructing South Africa's cities? The making of urban planning 1900-2000.Planning Perspectives.12:193-223. 1997.

[17] A. Todes,Urban spatial policy(In Pillay, U., Tomlinson, R. and Toit, J. du, (eds),Democracy and delivery: urban policy in South Africa.Cape Town: HSRC Press. 2006.

[18] V. Watson, The usefulness of normative planning theories in the context of Sub-Saharan Africa.Planning Theory. 1(1):2752. 2002.

[19] E. J. Cilliers, Creating Sustainable Urban Form: The Urban Development Boundary as a Planning Tool for Sustainable Urban Form: Implications for the Gauteng City Region.South Africa:Vdm Verlag. 2010.

[20] D. Dewar, \&R. Uytenbogaardt,South African cities: A manifesto for change.Cape Town:University of Cape Town. 1991.

[21] A.Mabin,Urban crisis, growth management and the history of metropolitan planning in South Africa.(Paper presented at the South African Institute of Town and Regional Planners conference of growth management and cities in crisis.Cape Town. 1994.

[22] A, Todes, A, Karam, N, Klug, N. Malaza,Beyond master planning? New approaches to spatial planning in Ekurhuleni, South Africa.Habitat International, 34:pp. 414-419. 2010.

[23] P. Harrison, A. Todes, $\&$ V. Watson,Planning and transformation: lessons from the South African experience.London:Routledge. 2008.

[24] A. Todes, Rethinking spatial planning.Town and Regional Planning. 53:10-14. 2008.

[25] I. Turok,Persistent polarization post-Apartheid? Progress towards urban integration in Cape Town, urban change and policy research group discussion paper 1.Glasgow:University of Glasgow. 2000.

[26] J. Friedmann,Globalization and the emerging culture of planning.Progress in Planning. 64(3): pp. 183-234. 2005.

[27] J. Friedmann,China's urban transition.Minneapolis, MN: University of Minnesota Press, Minneapolis. 2005.

[28] M.D. Schoonraad, Some reasons why we built unsustainable cities in South Africa. (In Strategies for a sustainable built environment). Department of Town and Regional Planning, University of Pretoria, Pretoria. August 2000.

[29] O. M. Amundsen, W. Allen, \&K.Hoellen, Green infrastructure planning: recent advances and applications.PAS Memo May/June. American Planning Association.2009. 